\title{
THERMAL STABILITY STUDY ON A NEW NI-CR-CO-MO-NB-TI-AL SUPERALLOY
}

\author{
Shuangqun Zhao ${ }^{1,2}$, Jianxin Dong ${ }^{1}$, Xishan Xie ${ }^{1}$, Gaylord D. Smith ${ }^{3}$, Shailesh J. Patel ${ }^{3}$ \\ ${ }^{1}$ High Temperature Materials Research Laboratories, University of Science and Technology Beijing; Beijing 100083, China \\ ${ }^{2}$ Department of Physics, Ningxia University; Yinchuan 750021, China \\ ${ }^{3}$ Special Metals Corporation; Huntington, WV 25705, USA
}

Keywords: Superalloy, Microstructural Stability, Precipitate, Corrosion Resistance

\begin{abstract}
A new precipitation-hardenable Ni-Cr-Co-Mo-Nb-Ti-Al superalloy for advanced ultra-supercritical boiler tubes is under development at Special Metals Corporation. This paper presents the results of a microstructural stability and corrosion resistance study on this new superalloy. The precipitates found in the alloy after aging at 704,725 and $760{ }^{\circ} \mathrm{C}$ are $\gamma^{\prime}, \eta, \mathrm{M}_{23} \mathrm{C}_{6}$, a minor amount of $\mathrm{G}$ phase and the stable carbide MC. The coarsening of $\gamma^{\prime}$ precipitates in the alloy follows a cube rate law: $\bar{r}^{3} \propto t$. The $\eta$ phase has been found to develop a Widmanstätten pattern structure following long exposure at elevated temperatures. The factors associated with structural instability of the alloy include the coarsening of $\gamma^{\prime}$, the formation of $\eta$ and $G$ phase. This alloy maintains good microstructural stability during prolonged aging at 704 and $725^{\circ} \mathrm{C}$. However, the stability may warrant improvement if the alloy is to be used at $760{ }^{\circ} \mathrm{C}$. The hot corrosion that occurs at $700{ }^{\circ} \mathrm{C}$ consists of two stages. The initial stage is controlled by a sulfidation mechanism and acidic fluxing mechanism serves the later stage. The presence of water vapor in air can accelerate oxidation of the alloy.
\end{abstract}

\section{Introduction}

The energy crisis and environmental restrictions have been exacerbated in recent years. This has prompted utilities to increase pressure and temperature of their pulverized coal-fired boilers so as to improve thermal efficiency and reduce $\mathrm{SO}_{\mathrm{x}}, \mathrm{NO}_{\mathrm{x}}$ and $\mathrm{CO}_{2}$ emissions. Today's boilers with efficiencies around $45 \%$ typically operate at a $30 \mathrm{MPa}$ steam pressure and $600{ }^{\circ} \mathrm{C}$ steam temperature. Typical superheater tubing, which are commonly employed, are austenitic stainless steels, such as TP304H, TP347H, Super304, and the Tempaloy series alloys, etc. Recent ultra-supercritical steam conditions up to 375 bar and $700{ }^{\circ} \mathrm{C}$, are being planned by both the European THERMIE project and the German MARCKO project, will enhance the efficiencies of coalfired boilers to about $50 \%$. The superheater and reheater materials will therefore be required to have high creep rupture strength $\left(\geq 100 \mathrm{MPa} / 10^{5} \mathrm{~h}\right)$ at a temperature of about $750{ }^{\circ} \mathrm{C}$, together with high corrosion resistance ( $\leq 2 \mathrm{~mm}$ cross-section loss in $2 \times 10^{5} \mathrm{~h}$ ). For long-term service at these high pressures and temperatures, neither solid solution austenitic heat-resisting steel nor a currently available nickel-base superalloy can fulfill these requirements for stress rupture strength and corrosion resistance [1 3].

NIMONIC $^{*}$ alloy 263 is a wrought Ni-Cr-Co base superalloy that has found application in gas turbines because of its stable microstructure, attractive creep strength and good oxidation resistance. On the basis of NIMONIC alloy 263, a new Ni-Cr-Co$\mathrm{Mo}-\mathrm{Nb}-\mathrm{Ti}-\mathrm{Al}$ superalloy, has been designed to meet these new stringent targets. The content of $\mathrm{Cr}$ and Mo in the new alloy has been adjusted for peak sulfidation resistance, while the strengthening element $\mathrm{Nb}$ has been added for additional high temperature strength as well. The new alloy requires the stress rupture strength no less than $100 \mathrm{MPa} / 10^{5} \mathrm{~h}$ at $750{ }^{\circ} \mathrm{C}$. However, the expected life is very long and the properties of the alloy can be greatly influenced by the degradation of microstructure. Additionally, severe corrosion problems may result from fireside attack to be envisaged for tubular components due to highly aggressive ash deposits that contain alkaline metals and sulfur from the coal. The objective of the present investigation is to examine the microstructure evolution during long-term aging at elevated temperatures and to study corrosion resistance of this new superalloy in laboratory-simulated pulverized coal-fired boiler environments and oxidation behavior of the alloy in air with water vapor. The structure stability and the possible corrosion mechanisms of the alloy are also discussed

\section{Experimental Procedure}

The chemical compositions of 3 heats new superalloy employed in this investigation are shown in Table 1 . The alloy was vacuum induction melted, and then vacuum arc remelted. The ingot was homogenized at $1204{ }^{\circ} \mathrm{C}$ for $16 \mathrm{~h}$ and subsequently hot worked to $15 \mathrm{~mm}$ bar at temperature no less than $1050{ }^{\circ} \mathrm{C}$. The bar was solution-annealed at $1150{ }^{\circ} \mathrm{C}$ for $30 \mathrm{~min}$ and water quenched.

Table 1. Chemical compositions of 3 heats new alloy (wt $\%$ ):

\begin{tabular}{|c|c|c|c|c|c|c|c|}
\hline Heat & $\mathrm{C}$ & $\mathrm{Cr}$ & $\mathrm{Co}$ & $\mathrm{Nb}$ & $\mathrm{Ti}$ & $\mathrm{Al}$ & $\mathrm{Mo}$ \\
\hline 1 & 0.034 & 24.31 & 19.63 & 1.83 & 1.58 & 0.75 & 0.52 \\
\hline 2 & 0.06 & 24.97 & 19.80 & 2.01 & 1.69 & 0.87 & 0.58 \\
\hline 3 & 0.032 & 22.96 & 19.27 & 1.87 & 1.63 & 0.72 & 0.51 \\
\hline
\end{tabular}

Continue

\begin{tabular}{|c|c|c|c|c|c|c|c|}
\hline Heat & $\mathrm{Fe}$ & $\mathrm{Si}$ & $\mathrm{Mn}$ & $\mathrm{Zr}$ & $\mathrm{S}$ & $\mathrm{P}$ & $\mathrm{Ni}$ \\
\hline 1 & 0.75 & 0.45 & 0.27 & 0.017 & 0.0022 & 0.003 & $\mathrm{Bal}$ \\
\hline 2 & 0.71 & 0.47 & 0.30 & 0.366 & 0.0018 & 0.013 & Bal \\
\hline 3 & 1.01 & 0.40 & 0.28 & 0.011 & 0.0022 & 0.002 & Bal \\
\hline
\end{tabular}

The specimens of Heat 1 after solution annealing were aged at 704,725 and $760{ }^{\circ} \mathrm{C}$ for $500,1000,2000$ and $4000 \mathrm{~h}$, respectively. The phase identification of these specimens was conducted on scanning electron microscope (SEM) and transmission electron microscope (TEM). Specimens for SEM examination were prepared by electrolytic polishing with a solution of $80 \% \mathrm{CH}_{3} \mathrm{OH}$ $+20 \% \mathrm{H}_{2} \mathrm{SO}_{4}$ and electrolytic etching with a solution of $170 \mathrm{ml}$ $\mathrm{H}_{3} \mathrm{PO}_{4}+15 \mathrm{~g} \mathrm{CrO}_{3}+10 \mathrm{ml} \mathrm{H}_{2} \mathrm{SO}_{4}$ after mechanical grounding to grit 800 paper. The specimens for TEM examination were ground to a thickness about 60 to $80 \mu \mathrm{m}$ and then electropolished in a solution containing $10 \% \mathrm{HClO}_{4}, 25 \% \mathrm{CH}_{3} \mathrm{CH}_{2} \mathrm{OH}$ and $65 \%$ $\mathrm{C}_{4} \mathrm{H}_{9} \mathrm{OH}$ at room temperature.

\footnotetext{
* NIMONIC and INCONEL are trade marks of the Special Metals Corporation group of companies
} 
The chemical compositions and weight fractions of the precipitates were ascertained through physical and chemical phase analyses. The $\gamma^{\prime}$ precipitates were electrolytically extracted in a water solution containing $1 \%\left(\mathrm{NH}_{4}\right)_{2} \mathrm{SO}_{4}$ and $1 \% \mathrm{C}_{6} \mathrm{H}_{8} \mathrm{O}_{7} \cdot \mathrm{H}_{2} \mathrm{O}$ at $0 \sim 5{ }^{\circ} \mathrm{C}$, and the mean radius of $\gamma^{\prime}$ precipitates was determined by using X-ray diffracto-spectrometer with Kratky small angle scattering goniometer (SAXS).

The pulverized coal-fired boiler environment was simulated as coal ash plus flue gas. All corrosion test specimens of Heat 2, coated with $5 \% \mathrm{Na}_{2} \mathrm{SO}_{4}+5 \% \mathrm{~K}_{2} \mathrm{SO}_{4}+90 \% \mathrm{Fe}_{2} \mathrm{O}_{3} / \mathrm{Al}_{2} \mathrm{O}_{3} / \mathrm{SiO}_{2}$ in 1:1:1 ratio, were exposed in a furnace with flowing gas of $\mathrm{N}_{2}+$ $15 \% \mathrm{CO}_{2}+3.5 \% \mathrm{O}_{2}+0.25 \% \mathrm{SO}_{2}$. The weight of coal ash on the specimens' surface was about $10 \mathrm{mg} \mathrm{cm}^{-2}$. The coating procedure was repeated for about every $500 \mathrm{~h}$ without cleaning the samples and the flow rate of pre-mixed flue gas was $200 \mathrm{ml} \mathrm{min}^{-1}$ during corrosion. Platinum foil was applied as a catalyst for the reaction: $2 \mathrm{SO}_{2}+\mathrm{O}_{2} \rightarrow 2 \mathrm{SO}_{3}$. The specimens were exposed at $700{ }^{\circ} \mathrm{C}$ for 116, 500, 1984 and $5008 \mathrm{~h}$, respectively. Additionally, the oxidation test on the samples of Heat 3 was performed in a flow of air with $10 \%$ water vapor at $750{ }^{\circ} \mathrm{C}$. After corrosion tests, the specimens were analyzed by using XRD and SEM with EDX.

\section{Results and Discussion}

\section{$\underline{\text { Basic Structure Analyses }}$}

As a starting point for structure study, the phase identification in this new alloy was firstly carried out by thermodynamic phase computation and then experimental phase determination for comparison.

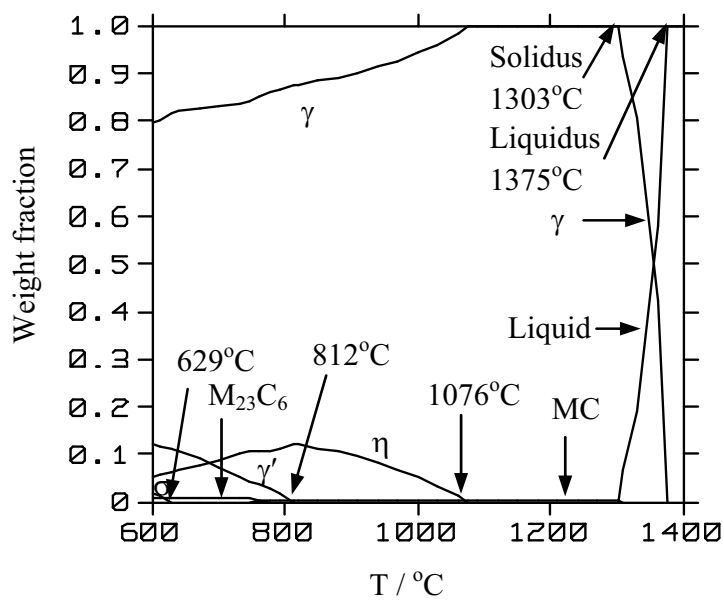

Figure 1. Phase diagram simulated by Thermo-Calc

Thermodynamic calculation was carried out to predict the phase stability and phase fractions in the alloy using Thermo-Calc software, version $\mathrm{M}$, accompanied with 14-element Ni-database. The calculated phase diagram of the alloy under equilibrium condition is shown in Figure 1, in which all the predicted equilibrium phases and their weight fractions at each temperature are given. Thermodynamic calculation (Figure 1) reveals that the equilibrium phases above $700{ }^{\circ} \mathrm{C}$ include $\gamma, \gamma^{\prime}, \eta, \mathrm{MC}$ and $\mathrm{M}_{23} \mathrm{C}_{6}$. The liquidus, solidus, $\eta$ and $\gamma^{\prime}$ solvus temperatures of the alloy are about $1375,1303,1076$ and $812{ }^{\circ} \mathrm{C}$, respectively. The predicted solidification temperature range $\left(72{ }^{\circ} \mathrm{C}\right)$ of this alloy is in good agreement with the experimental value $\left(74^{\circ} \mathrm{C}\right)$.
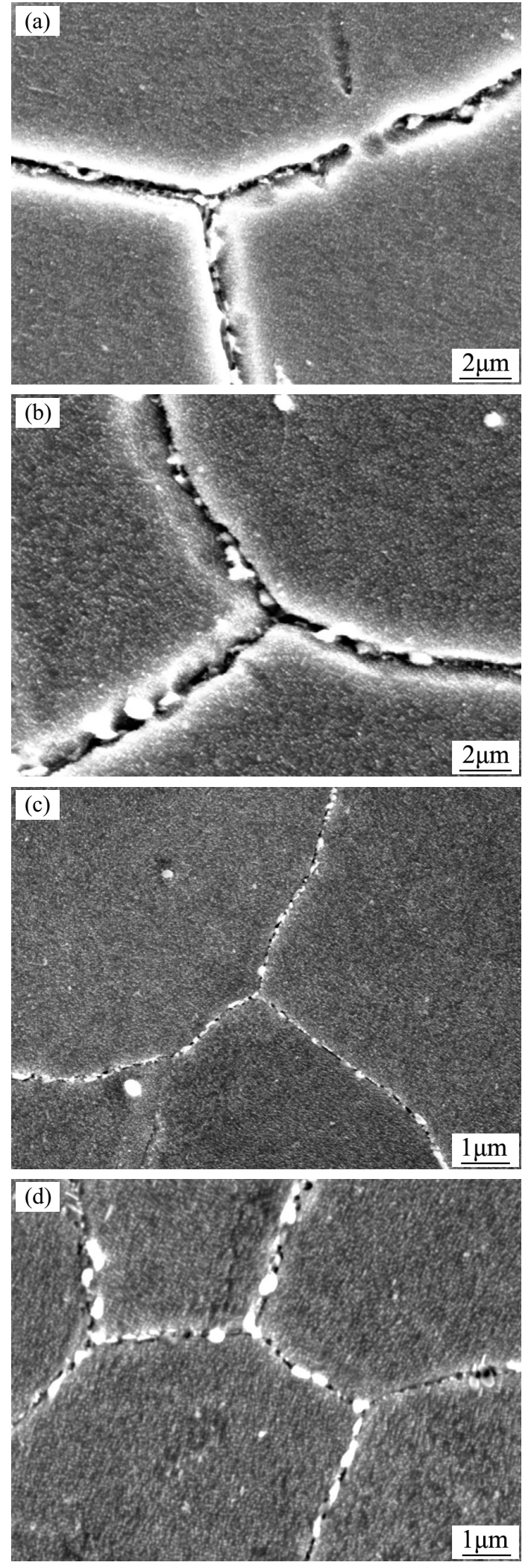

Figure 2. SEM images of Heat 1 aged at $704{ }^{\circ} \mathrm{C}$ for 500 (a), 1000 (b), 2000 (c) and $4000 \mathrm{~h} \mathrm{(d)}$ 

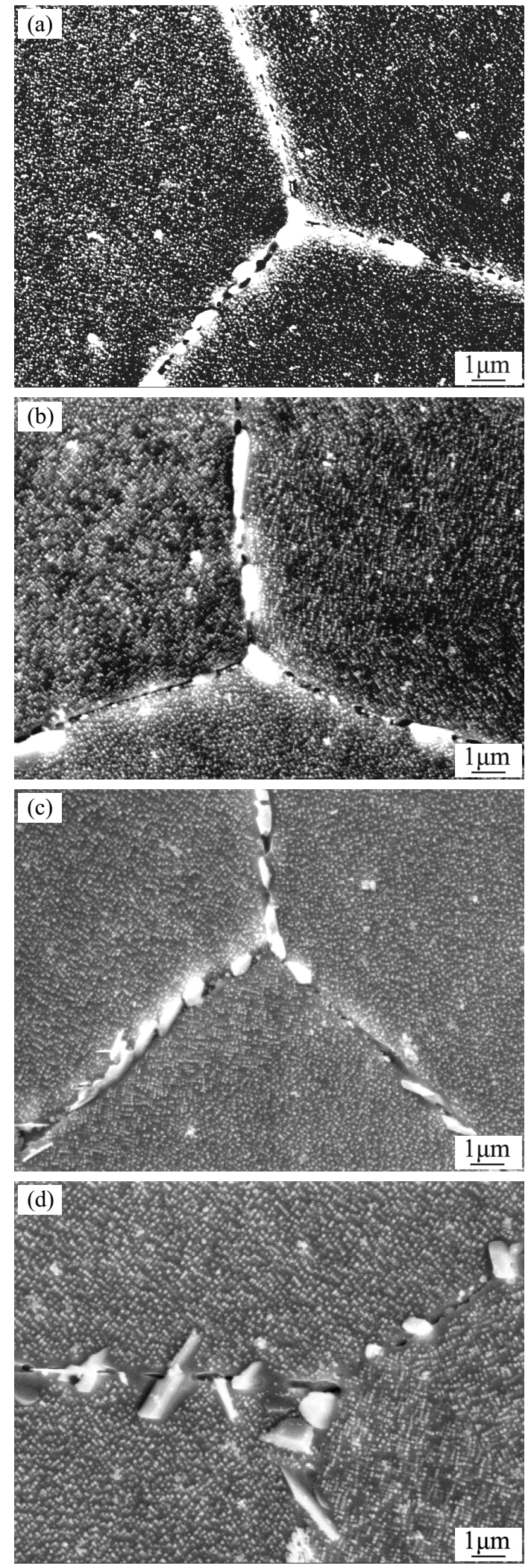

Figure 3. SEM images of Heat 1 aged at $725^{\circ} \mathrm{C}$ for 500 (a), 1000 (b), 2000 (c) and $4000 \mathrm{~h}(\mathrm{~d})$
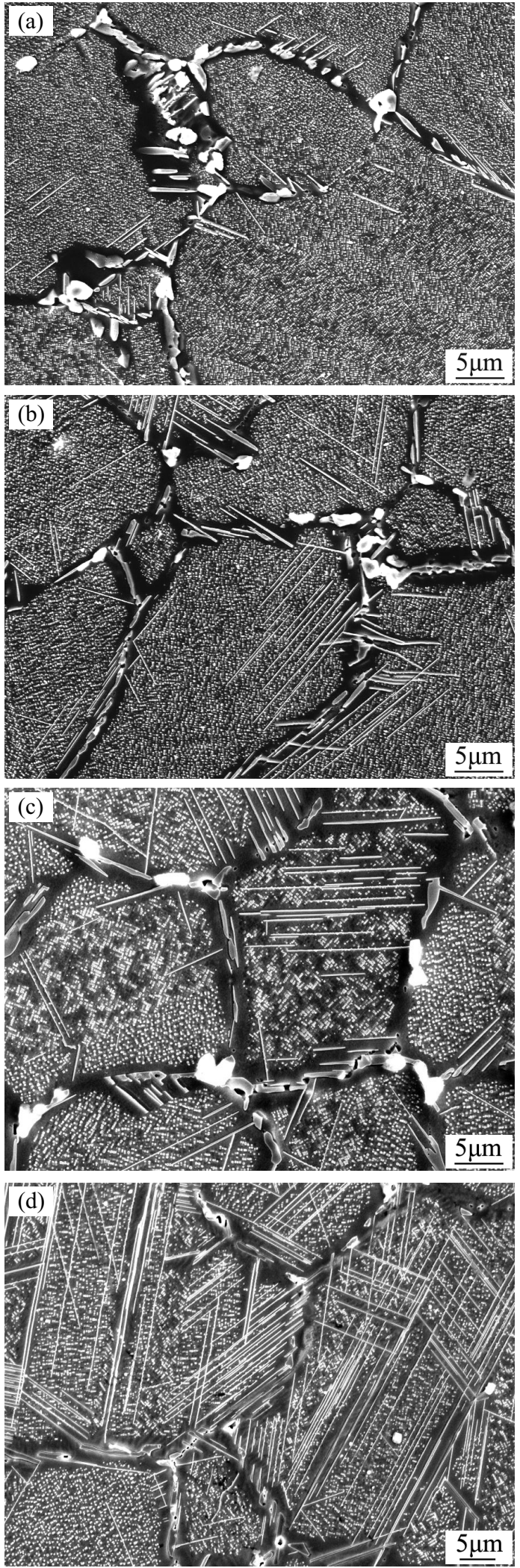

Figure 4. SEM images of Heat 1 aged at $760{ }^{\circ} \mathrm{C}$ for 500 (a), 1000 (b), 2000 (c) and $4000 \mathrm{~h}(\mathrm{~d})$ 
This new alloy is based on Ni-25Cr-20Co with Mo for solid solution strengthening and with $\mathrm{Nb}$, Ti and $\mathrm{Al}$ for $\gamma^{\prime}$ precipitation strengthening. Phase analyses results indicate that the weight fractions of $\gamma^{\prime}, \mathrm{MC}, \mathrm{M}_{23} \mathrm{C}_{6}$ and $\mathrm{G}$ phase in the sample of Heat 1 as standard heat-treatment $\left(1150^{\circ} \mathrm{C} / 30 \mathrm{~min} / \mathrm{WQ}+800{ }^{\circ} \mathrm{C} / 16 \mathrm{~h} / \mathrm{AC}\right)$ are $12.980 \%, 0.183 \%, 0.115 \%$ and $0.054 \%$, respectively. The lattice parameter $\left(\mathrm{a}_{0}\right)$ of $\gamma$-matrix is in the range of 3.59 3.60 $\AA$ and the lattice mismatch degree of $\gamma^{\prime}-\gamma$ is about $0.70 \%$.

\section{Microstructure Evolution at Long Time Aging}

SEM images of the samples of Heat 1 aged at $704{ }^{\circ} \mathrm{C}$ for 500 , 1000,2000 and $4000 \mathrm{~h}$ are shown in Figure 2. The morphology and distribution of precipitates in all samples are quite similar. Ultra fine $\gamma^{\prime}$ precipitates distribute in the grains, which contributes the main strengthening effect for the new alloy. The larger
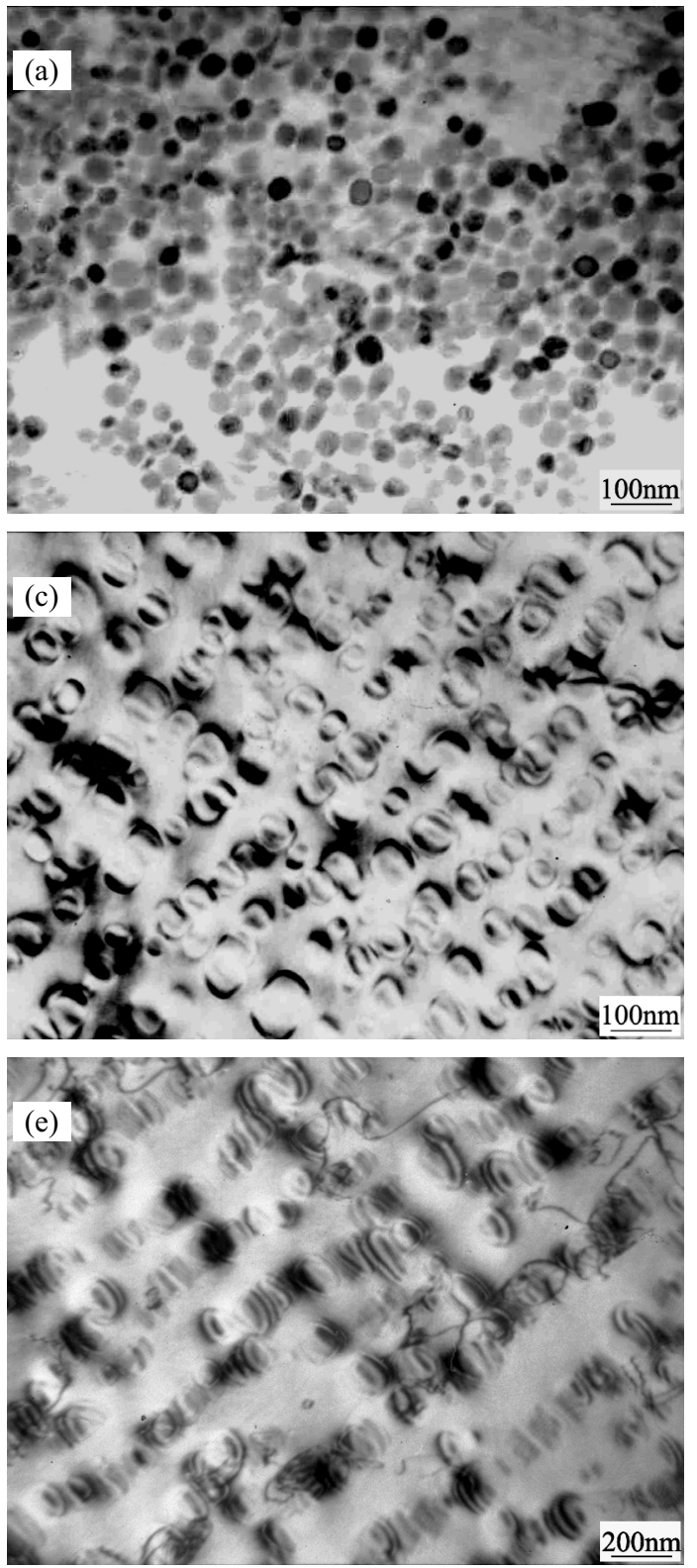

particles (MC) distribute in matrix at random. The grain boundary precipitates can be obviously observed after long time aging at $704^{\circ} \mathrm{C}$. The detailed phase analyses indicate that the major carbides are $\mathrm{MC}$ and $\mathrm{M}_{23} \mathrm{C}_{6}$. The $\mathrm{MC}$ and $\mathrm{M}_{23} \mathrm{C}_{6}$ are $(\mathrm{Nb}, \mathrm{Ti}) \mathrm{C}$ and $\mathrm{Cr}_{23} \mathrm{C}_{6}$-type carbide, respectively. The $\mathrm{MC}$ carbide forms from the liquid and it is stable for long time aging at high temperatures. $\mathrm{M}_{23} \mathrm{C}_{6}$ mainly forms at grain boundaries and have no significant variation with prolonged aging time.

Figure 3 shows SEM images of the samples aged at $725{ }^{\circ} \mathrm{C}$ for $500,1000,2000$ and $4000 \mathrm{~h}$. The morphology and distribution of precipitated phases in these samples are very similar to that of the samples aged at $704{ }^{\circ} \mathrm{C}$. However, after aging for $4000 \mathrm{~h}$ at 725 ${ }^{\circ} \mathrm{C}$,
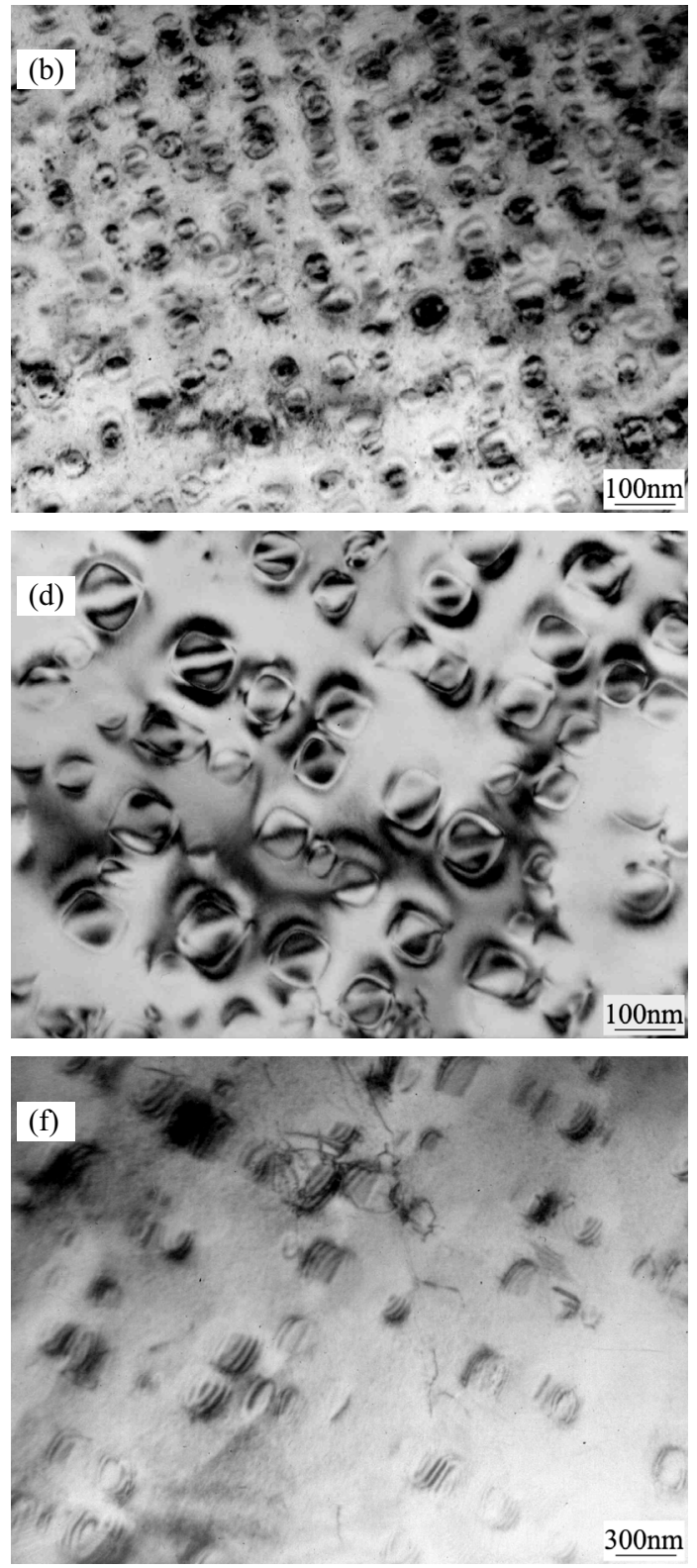

Figure 5. TEM morphologies of $\gamma^{\prime}$ precipitates of Heat 1 aged at $704{ }^{\circ} \mathrm{C}((\mathrm{a})$ and $(\mathrm{b})), 725{ }^{\circ} \mathrm{C}((\mathrm{c})$ and $(\mathrm{d}))$ and $760{ }^{\circ} \mathrm{C}((\mathrm{e})$ and $(\mathrm{f}))$ for 1000 $\mathrm{h}$ and $4000 \mathrm{~h}$ 
a small quantity of needle-like and blocky precipitates has formed mainly nearby grain boundaries.

Figure 4 shows SEM images of the samples aged at $760{ }^{\circ} \mathrm{C}$ for 500, 1000, 2000 and $4000 \mathrm{~h}$. The $\gamma^{\prime}$ precipitates can be seen clearly because of their growth at higher aging temperature. The significant structure change is $\eta$-phase formation. After $500 \mathrm{~h}$ aging, only small amount of $\eta$ phase forms in the matrix and nearby the grain boundaries. The quantity and size of $\eta$ precipitates rapidly increase with aging time. Till $4000 \mathrm{~h}$, not only $\eta$ phase initiates from grain boundaries but also a significant amount of $\eta$ phase forms in the grains as Widmanstätten pattern structure. In addition, there are $\gamma^{\prime}$-free zones surrounding $\eta$ plates. It indicates that the $\eta$ phase forms at the expense of $\gamma^{\prime}$ phase. The average chemical composition of $\eta$ precipitates analyzed by EDX is (in wt.\%): Ni 61.0, Cr 6.0, Co 10.0, Ti 12.3, Nb 7.3, Al 2.5. This stable hexagonal close-packed $\eta$ phase is $(\mathrm{Ni}, \mathrm{Cr}, \mathrm{Co})_{3}(\mathrm{Ti}, \mathrm{Nb})$ and can also dissolve a small amount of Al.

Attention should be paid that larger blocky particles have been formed at grain boundaries (Figure 4). This grain boundary phase is identified later as $\mathrm{G}$ phase.

Figure 5 gives the examples of the coarsening of $\gamma^{\prime}$ precipitates at 704,725 and $760{ }^{\circ} \mathrm{C}$ for 1000 and $4000 \mathrm{~h}$. It shows the growth of $\gamma^{\prime}$ precipitates with increasing aging time and temperature, particularly with temperature increasing. At initial stage of long time aging, the $\gamma^{\prime}$ particles are small and spherical. However, $\gamma^{\prime}$ particles are somewhat cuboidal with increasing aging time and temperature, which means $\gamma^{\prime}$ has a large lattice mismatch with $\gamma$ matrix.

The coarsening behavior of $\gamma^{\prime}$ particles was examined as a function of temperature from 704 to $760{ }^{\circ} \mathrm{C}$ and as a function of ageing time up to $4000 \mathrm{~h}$ for the alloy. The relationship between average effective radius of $\gamma^{\prime}$ precipitates obtained by SAXS in this alloy with various ageing time at three temperatures are plotted in Figure 6. It is clear that the relationships between effective radius $\bar{r}^{3}$ and ageing time $t$ at different aging temperatures are linear, suggesting that the coarsening of $\gamma^{\prime}$ particles in this new superalloy containing not too high volume fraction of $\gamma^{\prime}$ follows typical $\bar{r}^{3} \propto t$ kinetics of diffusioncontrolled particle growth (LSW Law). It is also an evidence in Figure 6 that the $\gamma^{\prime}$ particle coarsens more rapidly as the aging temperature increases.

\section{$\underline{\text { Results of Phase Analyses on Precipitates }}$}

The weight fractions of precipitates in the samples of Heat 1 aged at 704 and $760{ }^{\circ} \mathrm{C}$ for 1000 and $2000 \mathrm{~h}$ obtained by physical and chemical phase analyses are given in Table 2 . The results indicate that the precipitates in the alloy are $\gamma^{\prime}(+\eta), \mathrm{MC}, \mathrm{M}_{23} \mathrm{C}_{6}$ and $\mathrm{G}$ phase. Because of the similar electrochemical property, the $\gamma^{\prime}$ phase and the $\eta$ phase could not be differentiated by this method. The weight fraction of $\gamma^{\prime}$ precipitates in samples aged at $760{ }^{\circ} \mathrm{C}$ is total fractions of $\gamma^{\prime}$ and $\eta$. The actual fraction of $\gamma^{\prime}$ phase in the samples aged at $760{ }^{\circ} \mathrm{C}$ is less than that of at $704{ }^{\circ} \mathrm{C}$, because a certain amount of $\gamma^{\prime}$ has transformed to $\eta$. The fractions of $\gamma^{\prime}(+\eta)$, $\mathrm{MC}$ and $\mathrm{M}_{23} \mathrm{C}_{6}$ have no large changes with increasing time at temperatures 704 and $760{ }^{\circ} \mathrm{C}$. Phase analyses also indicate that the chemical composition of $\gamma^{\prime}$ precipitate is $\mathrm{Ni}_{3}(\mathrm{Ti}, \mathrm{Al}, \mathrm{Nb})$ and $\mathrm{G}$ phase is $\mathrm{A}_{6} \mathrm{~B}_{16} \mathrm{Si}_{7}$-type $(\mathrm{Nb}, \mathrm{Ti})_{6}(\mathrm{Ni}, \mathrm{Co})_{16} \mathrm{Si}_{7}$. It is worth to mention that the fractions of $\mathrm{G}$ phase in the samples aged at

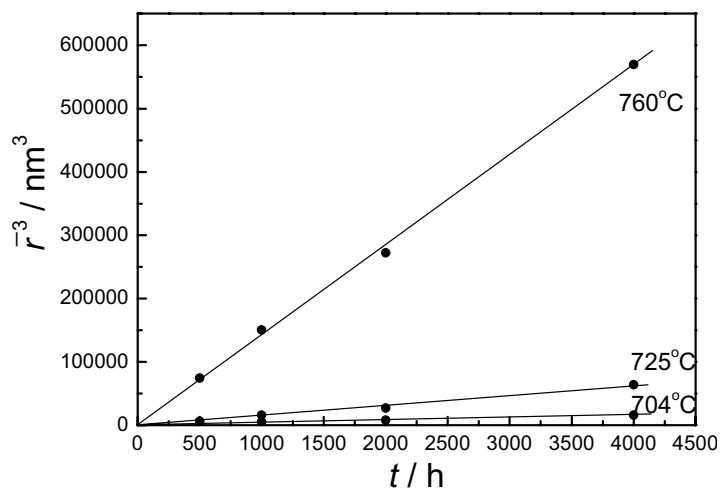

Figure 6. Coarsening of $\gamma^{\prime}$ precipitates in the alloy

Table 2. Fractions of the precipitates of Heat $1(\mathrm{wt} \%)$

\begin{tabular}{|c|c|c|c|c|}
\hline Heat-treatment & $\gamma^{\prime}(+\eta)$ & $\mathrm{MC}$ & $\mathrm{M}_{23} \mathrm{C}_{6}$ & $\mathrm{G}$ \\
\hline $704^{\circ} \mathrm{C} / 1000 \mathrm{~h}$ & 16.629 & 0.154 & 0.139 & 0.046 \\
\hline $704^{\circ} \mathrm{C} / 2000 \mathrm{~h}$ & 16.835 & 0.151 & 0.151 & 0.063 \\
\hline $760^{\circ} \mathrm{C} / 1000 \mathrm{~h}$ & 14.364 & 0.161 & 0.170 & 0.336 \\
\hline $760^{\circ} \mathrm{C} / 2000 \mathrm{~h}$ & 14.633 & 0.154 & 0.217 & 0.471 \\
\hline
\end{tabular}

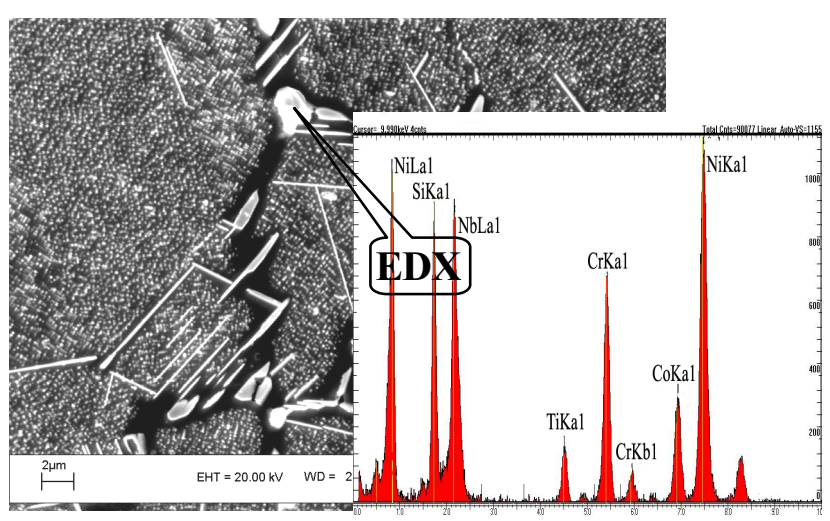

Figure 7. SEM image of G phase and EDX result in the sample aged at $760{ }^{\circ} \mathrm{C}$ for $1000 \mathrm{~h}$

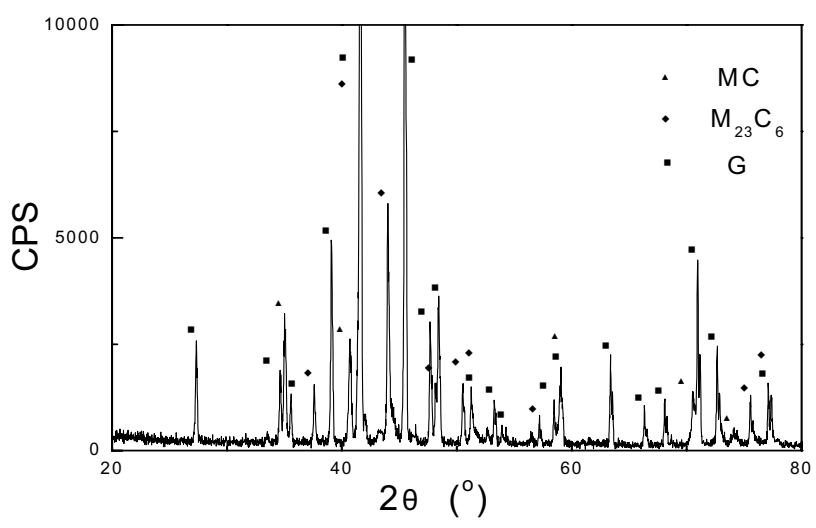

Figure 8. XRD spectra of the extracted phase in the sample aged at $760{ }^{\circ} \mathrm{C}$ for $4000 \mathrm{~h}$ 



Figure 9. Precipitation behavior of $\eta$ phase in the alloy $\left(725{ }^{\circ} \mathrm{C} / 4000 \mathrm{~h}(\mathrm{a}) ; 750{ }^{\circ} \mathrm{C} / 900 \mathrm{~h}(\mathrm{~b}) ; 800{ }^{\circ} \mathrm{C} / 100 \mathrm{~h}(\mathrm{c}) ; 850{ }^{\circ} \mathrm{C} / 50 \mathrm{~h}(\mathrm{~d}) ; 900{ }^{\circ} \mathrm{C} / 16\right.$ h (e); $\left.950{ }^{\circ} \mathrm{C} / 26 \mathrm{~h}(\mathrm{f})\right)$

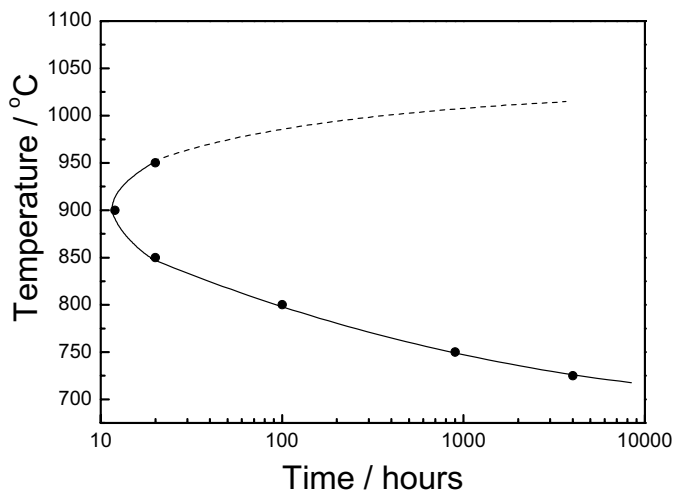

Figure 10. TTT diagram for $\eta$ in the alloy
$760{ }^{\circ} \mathrm{C}$ are much higher than those of at $704{ }^{\circ} \mathrm{C}$. Figure 7 shows a large particle of $\mathrm{G}$ phase at grain boundary in the sample of the alloy aged at $760{ }^{\circ} \mathrm{C}$ for $1000 \mathrm{~h}$ and EDX result shows that the atomic fraction of $\mathrm{Si}$ in the $\mathrm{G}$ phase is about $19.25 \%$. This result closes to the atomic fraction in a typical $\mathrm{G}$ phase $(24.14 \% \mathrm{Si})$. The XRD spectra of the electro-extracted phases of the sample aged at $760{ }^{\circ} \mathrm{C}$ for $4000 \mathrm{~h}$ is given in Figure 8.

\section{TTT-diagram of $\eta$ Formation}

Figure 9a, b, c, d, e and f show the SEM images of the samples of Heat 1 aged at $725{ }^{\circ} \mathrm{C}$ for $4000 \mathrm{~h}, 750{ }^{\circ} \mathrm{C}$ for $900 \mathrm{~h}, 800{ }^{\circ} \mathrm{C}$ for $100 \mathrm{~h}, 850{ }^{\circ} \mathrm{C}$ for $50 \mathrm{~h}, 900{ }^{\circ} \mathrm{C}$ for $16 \mathrm{~h}$ and $950{ }^{\circ} \mathrm{C}$ for $26 \mathrm{~h}$, respectively. In these samples, a small amount of $\eta$ phases formed at grain boundary and/or in matrix. In addition, the $\eta$ phase has 
not formed in the sample aged at $1000{ }^{\circ} \mathrm{C}$ for $140 \mathrm{~h}$. However, the experiment is difficult to find out when the $\eta$ phase really started to form. According to the results shown in Figure 9, the TTTdiagram for $\eta$ phase formation can be given approximately (Figure 10). Though no exact results at temperatures above 950 ${ }^{\circ} \mathrm{C}$, the trend of TTT-diagram is also given in accordance to the thermodynamics calculation, which indicates the highest stable temperature of $\eta$ phase is about $1087^{\circ} \mathrm{C}$. According to Figure 9, it is likely that the $\eta$ phase forms in the temperature range of $700 \sim 1087^{\circ} \mathrm{C}$. The peak value of precipitating speed of $\eta$ phase is about $900{ }^{\circ} \mathrm{C}$.

\section{Coal Ash/Flue Gas Corrosion Resistance}

Surface morphologies of the samples of Heat 2 after coal ash/flue gas corrosion tests at $700{ }^{\circ} \mathrm{C}$ for $116,500,1984$ and $5008 \mathrm{~h}$ are shown in Figure 11. The particles of corrosion products are very small and the grinding traces can be seen on the surface of samples, as shown in Figure 11a and b. This result indicates that the oxide scale is very thin. With an increase in time, the size of oxide particles and the thickness of oxide scale increase. EDX analyses show that there is no large difference in chemical compositions of corrosion products of the samples corroded for different times at $700{ }^{\circ} \mathrm{C}$. The corrosion products are rich in $\mathrm{Cr}$ and $\mathrm{O}$ and with a small amount of $\mathrm{Al}, \mathrm{Fe}, \mathrm{Si}, \mathrm{Ti}$ and $\mathrm{Co}$.

Cross-section images of the samples after corrosion at $700{ }^{\circ} \mathrm{C}$ for 116, 500, 1984 and $5008 \mathrm{~h}$ are presented in Figure 12. The samples exhibit broad, frontal attack with finger-like intrusions and isolated internal sulfide. The thickness of the scale increases with time and more internal sulfides can be found. As shown in Figure $12 \mathrm{a}, \mathrm{b}$ and $\mathrm{c}$, the oxide layers are compact, dense and adherent to the surface of the sample after corrosion for 116,500 and $1984 \mathrm{~h}$. However, after exposure for $5008 \mathrm{~h}$, a layered structure forms (Figure 12d). The outer layer is loose and porous and the inner layer is still compact and also has a good adherence to the matrix.

Figure 13 reveals X-ray mapping of the elements in the sample exposed at $700{ }^{\circ} \mathrm{C}$ for $5008 \mathrm{~h}$. The outer loose layer is rich in $\mathrm{Co}$, $\mathrm{Cr}, \mathrm{Ni}, \mathrm{Fe}, \mathrm{O}$ and with a small amount of $\mathrm{Al}$. A large amount of $\mathrm{Cr}$ and $\mathrm{O}$ as well as a trace amount of $\mathrm{Al}$ and $\mathrm{Ti}$ concentrate in the inner oxide layer. It should be noted that aluminum oxide distributes in the innermost of the oxide scale. Sulfur not only distributes at the scale/matrix interface but also concentrates in the internal penetrates. The internal penetrates are also enriched in $\mathrm{Cr}$ and $\mathrm{Ti}(\mathrm{Nb})$. X-ray mapping also shows severe $\mathrm{Cr}$-depletion in the internal penetration zone. For example, the fraction of $\mathrm{Cr}$ in $\mathrm{Cr}$ depletion zone is only about $7.4 \mathrm{wt} \%$ and the fraction of $\mathrm{Ni}$ and $\mathrm{Co}$ has increased to about $66.1 \mathrm{wt} \%$ and $24.5 \mathrm{wt} \%$, respectively. The scales formed on the samples after corrosion tests for 500 and $1984 \mathrm{~h}$ are similar to the inner layer of that for $5008 \mathrm{~h}$.

Figure 14 gives an example of XRD results of the samples after corrosion tests for 116 and $5008 \mathrm{~h}$. In combination of X-ray mapping with $\mathrm{X}$-ray diffraction results, the oxides in outer loose layer are identified as $\mathrm{CoCr}_{2} \mathrm{O}_{4}, \mathrm{Fe}(\mathrm{Cr}, \mathrm{Al})_{2} \mathrm{O}_{4}$ and $\mathrm{NiCr}_{2} \mathrm{O}_{4}$ spinels. The black particles in the outer layer are $\mathrm{SiO}_{2}$, which come from the coal ash. The inner layer of oxide scale is mainly composed of $\mathrm{Cr}_{2} \mathrm{O}_{3}$ with a small amount of $\mathrm{Al}_{2} \mathrm{O}_{3}$ and $\mathrm{TiO}_{2}$. The internal sulfides are identified as $\mathrm{CrS}$, $\mathrm{Ti}$ - and $\mathrm{Nb}$-sulfide.
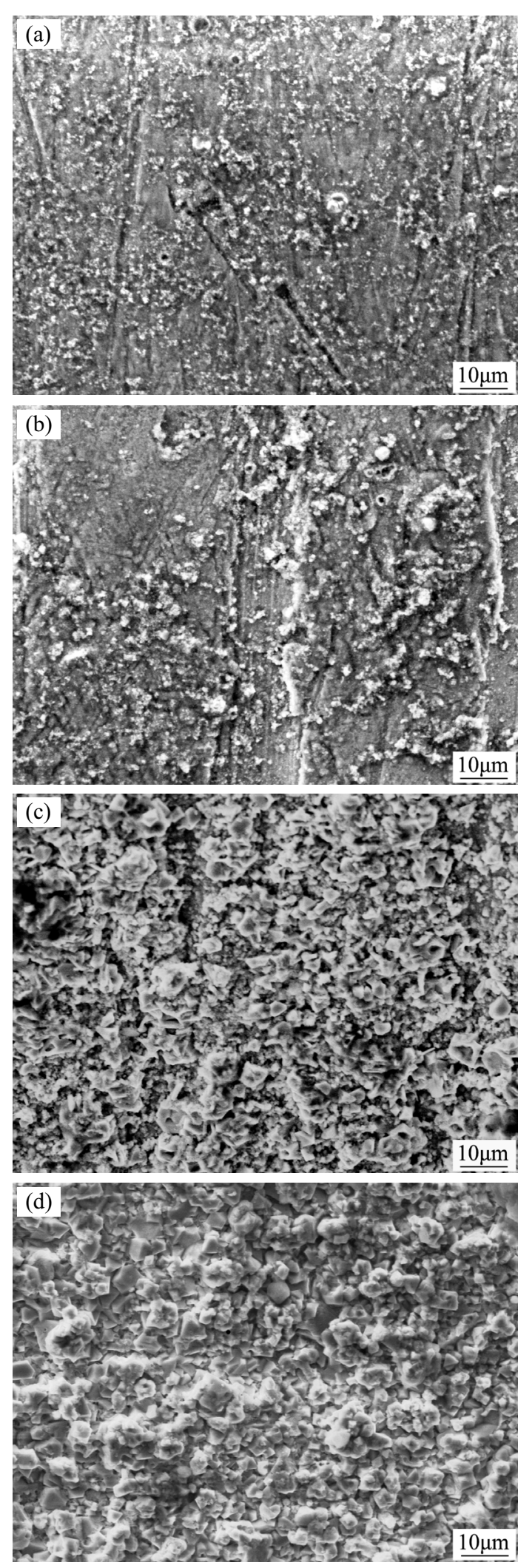

Figure 11. Surface morphologies of the samples of Heat 2 after corrosion at $700{ }^{\circ} \mathrm{C}$ for 116 (a), 500 (b), 1984 (c) and $5008 \mathrm{~h}(\mathrm{~d})$ 

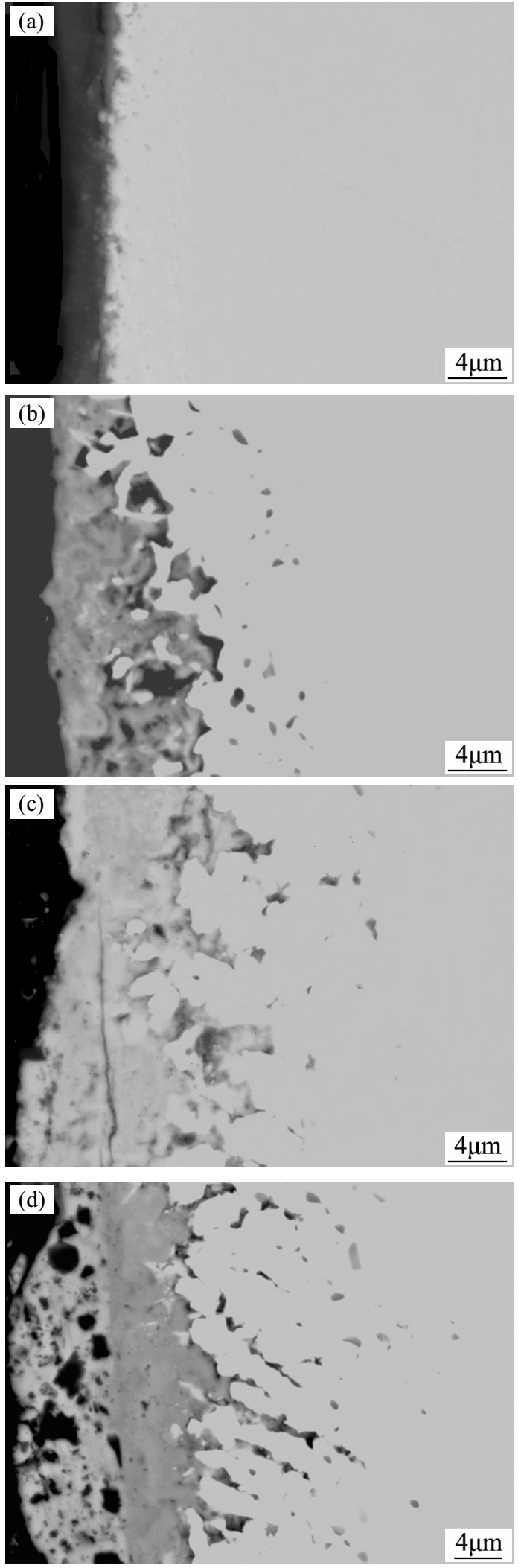

Figure 12. Cross-section images of the samples of Heat 2 after corrosion at $700{ }^{\circ} \mathrm{C}$ for 116 (a), 500 (b), 1984 (c) and $5008 \mathrm{~h}(\mathrm{~d})$
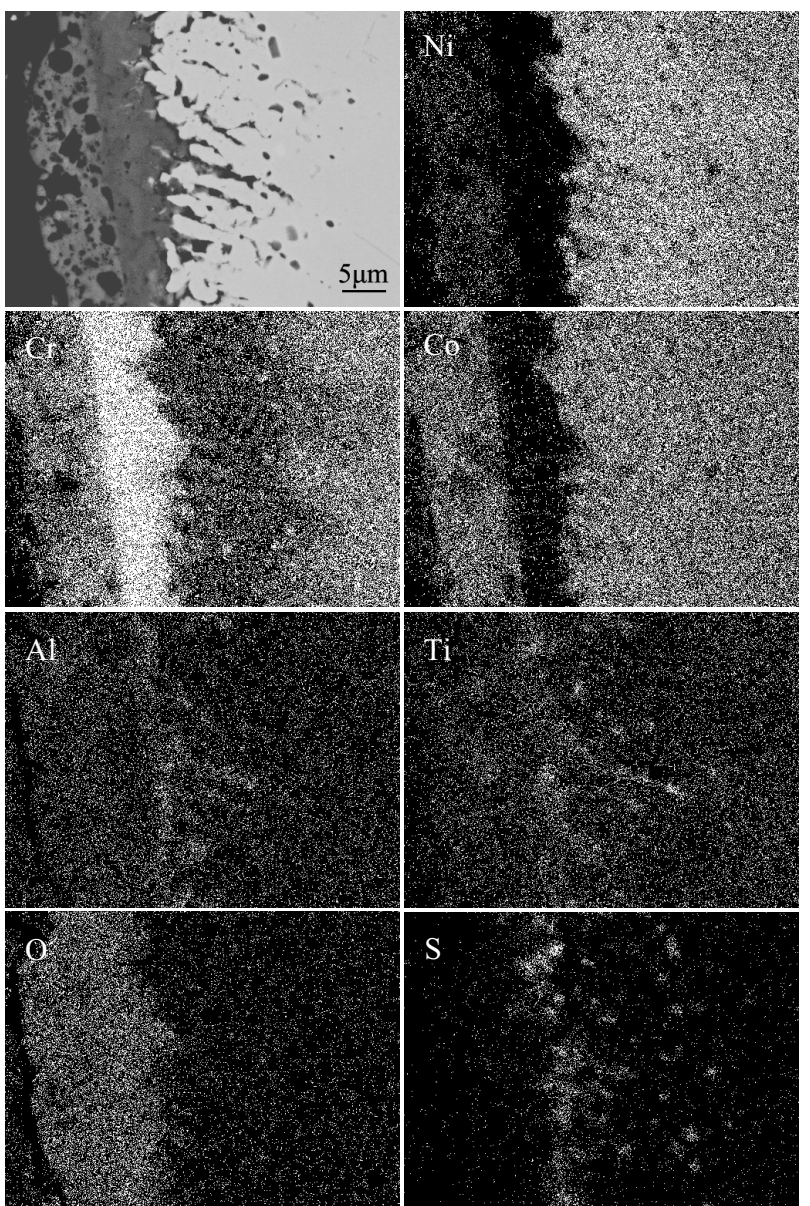

Figure 13. X-ray mappings of some elements of in the sample of Heat 2 after corrosion at $700{ }^{\circ} \mathrm{C}$ for $5008 \mathrm{~h}$

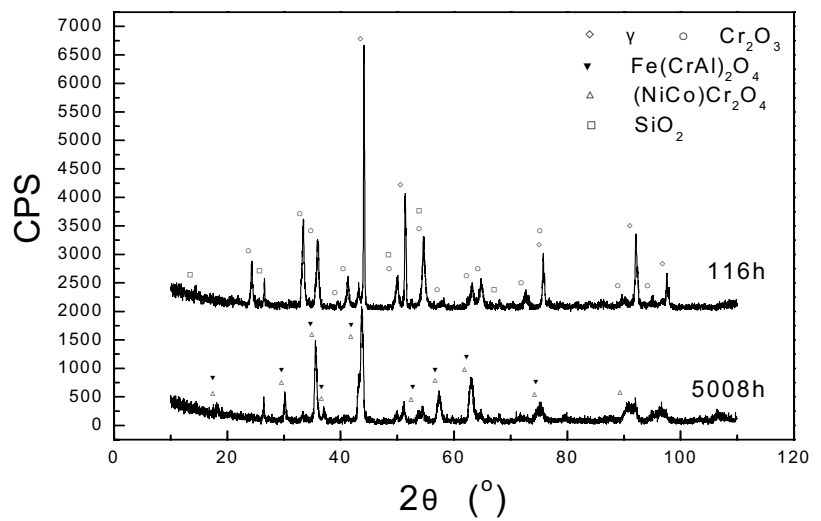

Figure 14. X-ray diffraction spectra of the sample of Heat 2 after corrosion at $700{ }^{\circ} \mathrm{C}$ for 116 and $5008 \mathrm{~h}$

\section{Corrosion Mechanism under Coal Ash/Flue Gas Environment}

$(\mathrm{Na}, \mathrm{K})_{3} \mathrm{Fe}\left(\mathrm{SO}_{4}\right)_{3}$ has been identified as the primary compound in the corrosive deposits on superheater tubes in coal-fired boilers which contributes to accelerated corrosion rates. The melting point of $(\mathrm{Na}, \mathrm{K})_{3} \mathrm{Fe}\left(\mathrm{SO}_{4}\right)_{3}$ is about $560{ }^{\circ} \mathrm{C}$. In this study, the partial pressure of $\mathrm{SO}_{3}$ is at the order of $10^{-3}$ atm and $\mathrm{Fe}_{2}\left(\mathrm{SO}_{4}\right)_{3}, \mathrm{NiSO}_{4}$ 
and $\mathrm{CoSO}_{4}$ are expected to be stable in contact with the $0.25 \%$ $\mathrm{SO}_{2}$-gas at $700{ }^{\circ} \mathrm{C}$. The melting points of $\mathrm{Na}_{2} \mathrm{SO}_{4}-\mathrm{CoSO}_{4}$ and $\mathrm{Na}_{2} \mathrm{SO}_{4}-\mathrm{CoSO}_{4}$ eutectic are $565{ }^{\circ} \mathrm{C}$ and $671{ }^{\circ} \mathrm{C}$, respectively. In gas environments containing $\mathrm{SO}_{3}$ partial pressure on the order of $10^{-3} \mathrm{~atm}$, no corrosion by basic fluxing and acidic fluxing of neither $\mathrm{Al}_{2} \mathrm{O}_{3}$ nor $\mathrm{Cr}_{2} \mathrm{O}_{3}$ should occur due to the positive gradient of the solubility at the scale/salt interface in acidic liquid salt [4].

Due to the existence of the sulfates on the surface of samples and the formation of the low melting point eutectics, the scales are expected to suffer accelerated attack by molten sulfates at $700{ }^{\circ} \mathrm{C}$. However, according to cross section morphology and structure analyses on the scale, the severe corrosion has not occurred until 1984 h. After that, the serious attack by molten sulfates has occurred and the loose outer scale, accompanied by a compact inner scale, has formed with increasing time.

The overall reaction that occurs at $700{ }^{\circ} \mathrm{C}$ can be divided into following two stages: an initial stage and a propagation stage.

At the initial stage of corrosion, $\mathrm{Cr}_{2} \mathrm{O}_{3}$ scale forms rapidly on the surface of the alloy due to high $\mathrm{Cr}$ content in the alloy with the internal oxidation reaction of some small amount elements such as $\mathrm{Al}$ and Ti taking place simultaneously. Although the sulfates on the surface of the alloy are in molten state, the fluxing of $\mathrm{Cr}_{2} \mathrm{O}_{3}$ can not occur and the oxide effectively protects the matrix from being attacked by molten salts. The deposits on the surface of alloy tend to lower the activity of oxygen and raise the activity of sulfur beneath the deposits. Various states of the sulfur, including $\mathrm{S}, \mathrm{S}^{2-}, \mathrm{SO}_{2}$, etc, diffuse inward through the cracks to the scale/metal interface and stable $\mathrm{CrS}$, $\mathrm{Ti}-$ and $\mathrm{Nb}$-sulfide form. With an increase in time, the previously formed sulfides will be oxidized and generate $\mathrm{S}$, some of which can then migrate further inward to form additional sulfide. Thus, both the pervious $\mathrm{Cr}_{2} \mathrm{O}_{3}$ layer and internal sulfides grow. The scale/alloy interface also migrates inward.

With the increase of Cr-depletion and the relative higher content of $\mathrm{Co}$ and $\mathrm{Ni}$ in internal penetration zone, corrosion is gradually progressing to the propagation stage and the acidic fluxing of the scale occurs. Due to the high diffusion rate of $\mathrm{Co}$ in the scale, $\mathrm{CoO}$ forms on the exterior part of the scale. $\mathrm{CoO}$ particles are surrounded by $\mathrm{Cr}_{2} \mathrm{O}_{3}$ and the solid-state reaction occurs to form $\mathrm{CoCr}_{2} \mathrm{O}_{4}$ spinel in the outer layer of the scale gradually. Subsequently, $\mathrm{CoO}$ and a small amount of $\mathrm{NiO}$ form on the surface of the scale. Since the thermodynamic stability of $\mathrm{NiSO}_{4}$ is much lower than that of $\mathrm{CoSO}_{4}$ and $\mathrm{CoO}$ is better than $\mathrm{NiO}$ as the catalyst to stabilize the $\mathrm{SO}_{3}, \mathrm{CoSO}_{4}$ is expected to form preferentially. Corrosion induced by molten sulfates enters to the accelerated stage. High $\mathrm{SO}_{3}$ partial pressure is required to stabilize the low melting point solution of sulfates. The reaction proceeds by the inward migration of $\mathrm{SO}_{3}$ and outward migration of cobalt. At longer times when the liquid salt is saturated with cobalt, only the cobalt dissolves at the scale/salt interface to form $\mathrm{CoO}$ in molten sulfates. In the $\mathrm{Co}^{3+} / \mathrm{Co}^{2+}$ exchange reaction, $\mathrm{Co}^{3+}$ may be replaced with $\mathrm{Fe}^{3+}$ and then iron oxide will form in molten sulfates $[5,6]$. Various oxides form spinels by solid-state reaction.

The experimental results show that nickel-base alloys are in general more resistant to low temperature hot corrosion than cobalt-base alloys. A small increase in $\mathrm{Cr}$ level and decrease in Co level will act in a beneficial way to resist coal ash corrosion. The increase in $\mathrm{Cr}$ content may result in precipitation of TCP phases, such as $\sigma$ phase, which will develop a harmful effect on mechanical properties of the alloy. However, the decrease in $\mathrm{Co}$ content not only prevents the formation of $\sigma$ phase but also benefits to the formation of pure $\mathrm{Cr}_{2} \mathrm{O}_{3}$ scale and retards the sulfidation and dissolution of cobalt oxide. More evaluations are needed to consider the effect of the increase in $\mathrm{Cr}$ level and the decrease in Co level on the overall properties of the alloy.

\section{Oxidation in Air with 10\% Water Vapor}

The mass change curve for the sample of Heat 3 oxidized at $750^{\circ} \mathrm{C}$ for $2480 \mathrm{~h}$ in air with $10 \%$ water vapor is shown in Figure 15. The sample was cycle to room temperature approximately once per week for mass measurement. The oxidation behavior basically follows the parabolic law. The rate of mass gain increases rapidly at initial stage of oxidation $(<500 \mathrm{~h})$ and then slows with time. However, mass gain results obtained at same temperature in air without water vapor were much lower. It is apparent that the addition of water vapor does accelerate the oxide growth rate.

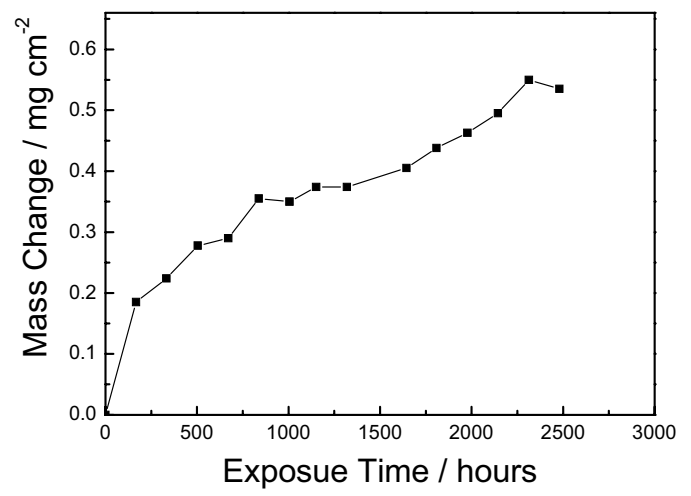

Figure 15. Mass change behavior of the samples (Heat 3) oxidized at $750{ }^{\circ} \mathrm{C}$ for $2480 \mathrm{~h}$ in air with $10 \%$ water vapor

The cross-section image of the scale and X-ray mapping of some elements in the scale are shown in Figure 16. The oxide scale is composed of an external oxide layer and an internal penetration zone. The external oxide layer has been found to be not compact and adherent to the surface. The cracks in the scale may be associated with the stress developed in the oxide layer during cooling from high temperature. The oxides formed in the outer scale are rich in $\mathrm{Cr}$, $\mathrm{Ti}$ and $\mathrm{O}$. Small amounts of $\mathrm{Ni}$ and $\mathrm{Co}$ are also found in this region. The oxides formed in this layer are comprised mostly of $\mathrm{Cr}_{2} \mathrm{O}_{3}$, with some $\mathrm{TiO}_{2}$ and a small amount of $(\mathrm{Ni}, \mathrm{Co}) \mathrm{Cr}_{2} \mathrm{O}_{4}$. The internal oxides are rich in $\mathrm{Al}$, Ti and $\mathrm{O}$ and identified as $\mathrm{Al}_{2} \mathrm{O}_{3}$ and $\mathrm{TiO}_{2}$.

The influence of water vapor on high temperature oxidation of chromia-forming $\mathrm{Fe}-\mathrm{Cr}$ and $\mathrm{Fe}-\mathrm{Cr}-\mathrm{Ni}$ alloys has received considerable attention. The possible explanations proposed for water vapor effect can be: (1) increasing the mass transport of oxygen through iron oxide, (2) forming gaseous iron hydroxide leading to increased mass transport of iron through the scale, (3) increasing the diffusion rate of chromium through chromium oxide and (4) causing the vaporization of chromium oxide hydroxide [7]. However, only a few works deal with the influence of water vapor on the oxidation of $\mathrm{Ni}-\mathrm{Cr}$ alloys. Due to the insufficiency of the experimental results in this study, the detailed 
explanation of the effect of water vapor on the oxidation of this superalloy could not be gained. A basic analysis on the oxidation mechanism of this superalloy is proposed in this study.
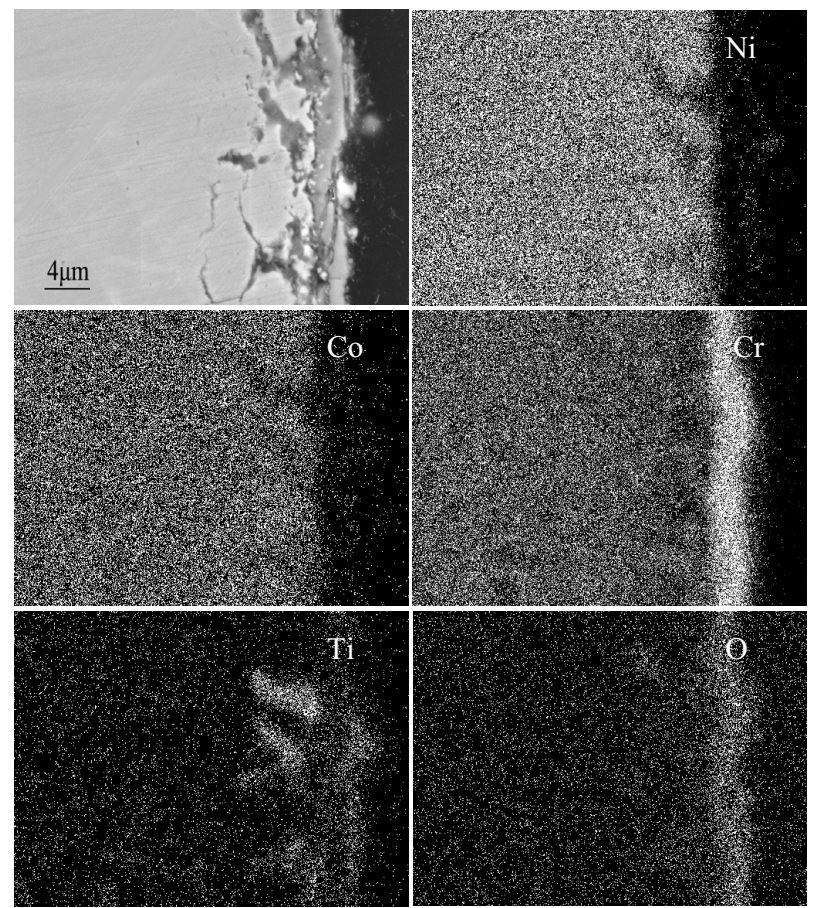

Figure 16. Cross-section image of the sample after corrosion for $2480 \mathrm{~h}$ at $750{ }^{\circ} \mathrm{C}$ in air with $10 \% \mathrm{H}_{2} \mathrm{O}$ and $\mathrm{X}$-ray maps of elements

At the initial oxidation stage, some kinds of oxides, $(\mathrm{Ni}, \mathrm{Co}) \mathrm{O}$ and $\mathrm{Cr}_{2} \mathrm{O}_{3}$, etc, form on the surface of specimens and the internal oxidation reaction of some elements takes place simultaneously. Because of the high concentration of chromium in the alloy, the continuous $\mathrm{Cr}_{2} \mathrm{O}_{3}$ film forms quickly on the alloy surface with subsequent growth and the oxidation of nickel and cobalt is inhibited. (Ni,Co)O particles were surrounded with $\mathrm{Cr}_{2} \mathrm{O}_{3}$ and the solid-state reaction occurs to form $(\mathrm{Ni}, \mathrm{Co}) \mathrm{Cr}_{2} \mathrm{O}_{4}$ spinel in the scale gradually and distributes in the external oxide layer. Due to the high stability of $\mathrm{Al}_{2} \mathrm{O}_{3}$ and $\mathrm{TiO}_{2}, \mathrm{Al}$ and $\mathrm{Ti}$ can be selectively oxidized at the matrix/oxide interface and internally oxidized in the matrix even though they are at a relatively low concentration. It is likely that water vapor induces the increased transport of $\mathrm{Cr}$ ions and also induces the evaporation of chromia.

\section{Conclusions}

1. The precipitates observed in a new Ni-Co-Cr-Mo-Nb-Ti-Al superalloy aged at 704,725 and $760{ }^{\circ} \mathrm{C}$ are $\gamma^{\prime}, \eta, \mathrm{M}_{23} \mathrm{C}_{6}, \mathrm{G}$ phase and stable $\mathrm{MC}$. The $\gamma^{\prime}, \mathrm{MC}, \mathrm{M}_{23} \mathrm{C}_{6}$ and $\mathrm{G}$ phase are mainly composed of $\mathrm{Ni}_{3}(\mathrm{Ti}, \mathrm{Al}, \mathrm{Nb}), \quad(\mathrm{Nb}, \mathrm{Ti}) \mathrm{C}, \quad \mathrm{Cr}_{23} \mathrm{C}_{6} \quad$ and $(\mathrm{Nb}, \mathrm{Ti})_{6}(\mathrm{Ni}, \mathrm{Co})_{16} \mathrm{Si}_{7}$, respectively. The fractions of $\gamma^{\prime}(+\eta)$ and $\mathrm{M}_{23} \mathrm{C}_{6}$ in the alloy exhibit no large changes as a result of thermal exposure but the fraction of $\mathrm{G}$ phase increases rapidly with an increase in temperature.

2. The main structure instability at high temperature of this new alloy except the $\gamma^{\prime}$ coarsening is mainly following 2 aspects: the formation of large amount of $\eta$ phase and high fraction of $G$ phase. The $\gamma^{\prime}$ particles exhibit cuboidal shape and follow a coarsening behavior of the cube rate law: $\bar{r}^{3} \propto t$. The $\eta$ phase can develop to a Widmanstätten pattern structure at higher aging temperature. The alloy keeps a good microstructural stability during prolonged aging at 704 and $725{ }^{\circ} \mathrm{C}$, but the structure stability of the alloy needs to be improved at $760{ }^{\circ} \mathrm{C}$.

3. Low temperature hot corrosion of the alloy, results from the formation of low melting sulfates eutectics at $700{ }^{\circ} \mathrm{C}$ under the coal ash/flue gas environments, consists of two stages. The sulfidation of the alloy takes place at initial stage and the fluxing mechanism serves to the propagation stage. The internal sulfidation proceeds with increasing time.

4. The presence of water vapor leads to a significant acceleration in oxidation of the new alloy. The overall rate of oxidation remains low.

5. The investigated new Ni-Co-Cr-Mo-Nb-Ti-Al alloy, designated as INCONEL ${ }^{*}$ alloy 740 by Special Metals Corporation, is still under development. It offers a good microstructural stability, high creep strength, and excellent resistance to corrosive attack at expected service temperatures and exhibits a bright future for high temperature application in the power industries.

Acknowledgement: This project is supported by Special Metals Corporation, Huntington WV, USA.

\section{References}

1. G. D. Smith et al, "The corrosion resistance of nickelcontaining alloys in coal-fired boiler environments" (Paper presented at Corrosion 99, San Antonio, TX, 25-30 Apr. 1999), 12.

2. G. D. Smith et al, "Introduction of an advanced superheater alloy for coal-fired boilers" (Paper presented at Corrosion 2000, Orlando, FL, 26-31 Mar. 2000), 00256.1.

3. P. Castello et al, "Laboratory-simulated fuel-ash corrosion of superheater tubes in coal-fired ultra-supercritical-boilers', Materials and Corrosion, 51 (2000), 786-790.

4. J. Stringer, "High-temperature corrosion of superalloys", Mater. Sci. Technol., 3 (1987), 482-493.

5. K. L. Luthra, "Low temperature hot corrosion of cobalt-base alloys: Part I. Morphology of the reaction product", Metall. Trans. A, 13A (1982), 1843-1852.

6. K. L. Luthra, "Low temperature hot corrosion of cobalt-base alloys: Part II. Reaction mechanism", Metall. Trans. A, 13A (1982), 1853-1864.

7. H. Asteman et al, "Oxidation of 310 steel in $\mathrm{H}_{2} \mathrm{O} / \mathrm{O}_{2}$ mixtures at $600^{\circ} \mathrm{C}$ : the effect of water-vapor-enhanced chromium evaporation", Corros. Sci., 44 (2002), 2635-2649. 